This is the peer reviewed version of the following article: Hamari L., Heinonen O.J., Aromaa M., Asanti R., Koivusilta L., Koski P., Laaksonen C., Matomäki J., Pahkala K., Pakarinen A., Suominen S., Salanterä S (2017) Association of Self-Perceived Physical Competence and Leisure-Time Physical Activity in Childhood : A Follow-Up Study, which has been published in final form at http://dx.doi.org/10.1111/josh.12490. This article may be used for noncommercial purposes in accordance with Wiley Terms and Conditions for Self-Archiving.

\title{
Association of self-perceived physical competence and leisure-time physical activity in childhood - a follow-up study
}

\author{
ABSTRACT \\ BACKGROUND: The basis of self-perceived physical competence is built in \\ childhood and school personnel have an important role in this developmental \\ process. The aim of this study was to investigate the association between initial \\ self-perceived physical competence and reported leisure-time physical activity \\ (LTPA) longitudinally in 10, 12 and 15-year-old children.
}

METHODS: This longitudinal follow-up study comprises subjects from an elementary school cohort $(\mathrm{N}=1346)$ in the city of Turku, Finland (175 000 inhabitants). The self-perceived physical competence (fitness and appearance) and LTPA data were collected with questionnaires. The full longitudinal data was available from 571 subjects based on repeated studies at the age of 10, 12 and 15 in 2004, 2006 and 2010. The association with self-perceived physical competence and LTPA was analyzed with regression models.

RESULTS: The self-perceived physical competence was positively associated with LTPA at all ages $(10$ years $p<.05,12$ years $p<.0001,15$ years $<.0001)$. Increase in the self-perceived physical fitness scores was likely to associate with higher LTPA at each age point $(10$ years $[\mathrm{OR}]=1.18 ; 95 \%$ CI:1.09-1.27, 12 years $[\mathrm{OR}]=1.27 ; 95 \% \mathrm{CI}: 1.18-1.37$, and 15 years $[\mathrm{OR}]=1.28 ; 95 \% \mathrm{CI}: 1.19-1.38)$.

CONCLUSIONS: Self-perceived physical competence is associated with LTPA in children and adolescents, and the association is strengthened with age. 
Keywords: children; physical activity; self-perceived physical competence;

follow-up study 
Self-perceived physical competence is defined as an individual's own estimate of his or her general physical capabilities. ${ }^{1}$ It is particularly important for the development of a good self-esteem. ${ }^{2}$ Self-esteem refers to "the degree to which individuals feel positive about themselves". ${ }^{1}$

Self-perceived physical competence is closely related to self-efficacy which is defined as a belief in one's own ability to succeed in particular situations. ${ }^{3}$ Interventions that focus on promoting good self-efficacy may be more effective in physical activity promotion than those that do not take motivational factors into consideration. ${ }^{4}$ Specifically, the role of self-perceived physical competence is important in the promotion of physical activity since physical self-efficacy is an important construct of self-esteem and physical activity. ${ }^{5}$ Physical education and physical activity promotion programmes may also have negative effects on self-esteem when used inappropriately. ${ }^{6}$

Physical activity recommendations indicate that 5-17-year-old children should accumulate daily at least one hour moderate to vigorous physical activity. ${ }^{7,8}$ Moreover, sedentary and screen time should be limited to daily two hours. ${ }^{9}$

Physical activity has several benefits to health and wellbeing including increased muscular and cardiovascular fitness, healthier body composition, improved bone health, better sleep quality, and improved cognitive function ${ }^{10}$ as well as beneficial effects on self-concept, anxiety, depression symptoms and academic performance. ${ }^{8}$ In addition, basic motor skills develop in early childhood and the ground for physical fitness and skills is build. ${ }^{11}$ It is also known that physical activity in adolescence is associated with physical activity in adulthood. ${ }^{12}$ A physically active lifestyle is shown to develop very early in childhood and the persistence of physical activity from youth to adulthood is moderate or high. ${ }^{13}$ Physical inactivity is a risk factor for obesity, chronic diseases, such 
as type two diabetes and cardiovascular diseases, osteoporosis, some cancers and potentially depression. ${ }^{10}$ In addition, motor difficulties are associated with physical inactivity ${ }^{14,15}$ as well as low levels of psychosocial well-being, cognitive functioning and educational achievement. ${ }^{16,17}$

In spite of the awareness of the recommendations and the great benefits of physical activity, only a small number of children in Western countries encounter the recommended levels of daily activity. ${ }^{18}$ Children aged 10 years or younger tend to be physically active, but the activity levels significantly decrease between ages 11 and 15 . 19, 20 The decrease in physical activity in adolescence is a global phenomenon - strongly evident also in the Finnish youth. ${ }^{21}$

Positive experiences of childhood physical activity awaken the motivation to physical activity and form the foundation for future health and wellbeing ${ }^{22}$, as well as for life-long physical activities. ${ }^{23}$ Factors motivating physical activity in children and adolescents are e.g. fun, skill development, fitness, affiliation or social cohesion, challenge and success. ${ }^{24,25}$ In a recent Finnish twin study, physical fitness, enjoyment, psychological state, mastery and appearance were the highest motivating factors to engage in LTPA. ${ }^{26}$

Teenagers' physical activity is highly influenced by self-esteem since teenagers often identify physical activity as an `aspect of the self`. Teenagers with poor selfesteem and poor perceived health status are found to exercise less. ${ }^{27}$ However, there is discrepancy across the studies about the associated factors with physical activity. ${ }^{28}$ Recent studies have also shown that the motivational factors in physically active and inactive people differs. ${ }^{26}$ 
Even though we know that the lack of self-perceived physical competence is a major factor for low physical activity in children and adolescents ${ }^{28,29}$, and that selfesteem is positively influenced by adolescent physical activity ${ }^{12}$, it is still unclear how these associations change from childhood to early adolescence and what factors of selfperceived physical competence in particular (e.g. perceived physical skills, agility, flexibility, endurance, speed, strength or courage) are the key elements.

The aim of this study was to investigate the association between self-perceived physical competence and LTPA longitudinally at the ages of 10, 12, and 15 . We also studied how the association between activity level and self-perceived physical competence changed over time from 10 to 12 and 15 years of age.

Our hypotheses were that (1) The self-perceived physical competence scores are inversely associated with age and (2) The associations between the self-perceived physical competence and LTPA is strengthened with age.

The study follows the methodological guidelines for cohort studies outlined in the STROBE Statement. ${ }^{30}$

\section{METHODS}

We used a longitudinal cohort study design and the data were collected by crosssectional surveys from the same cohort at three time points in 2004, 2006, and 2010.

\section{Subjects}

The study population comprised of all 10-year-old (2004) school children $(\mathrm{N}=1346)$ from 31 eligible Finnish speaking comprehensive schools in the city of Turku (175 000 inhabitants) in Finland. Two follow-ups were completed in the same 
population at the age of 12 (2006) and 15 (2010). Only individuals with data at all three measurement points were included in this study. Altogether 571 children (girls $\mathrm{N}=299$, $52.4 \%$; boys $\mathrm{N}=272,47.6 \%$ ) had a complete data set at all three time points. The study is part of the Turku Schools on the Move research project. Other publications of the project are related to school children's health related quality of life. ${ }^{31,32}$

\section{Instruments}

Self-perceived physical competence. The self-perceived physical competence was measured as described by Lintunen. ${ }^{2}$ This questionnaire has been widely used in 10 - to 18-year-old children in Finland and it is validated for healthy children from age 10 to 15 years $^{2,33,34}$ and for 13- to 18-year-old children with disabilities. ${ }^{35}$

The questionnaire includes a total of ten questions (seven at the fitness subscale and three at the appearance subscale) and each question is estimated on a 5-point Osgood semantic differential scale. The seven questions of the self-perceived physical fitness subscale focus on physical skills, agility, flexibility, endurance, speed, strength and courage. On the scale of 1-5 the lowest value indicates poor and the highest very good perceived physical fitness. ${ }^{35}$ The sum index of the perceived fitness subscale varies between 7-35 and accordingly the score of 21 indicates a neutral value. ${ }^{34}$

The three components of self-perceived appearance are: appearance, height and body weight. The perception of appearance were asked by a question 'I am satisfied with my appearance' and rated as 1-2-3-4-5 where number 1 indicates the poorest level of satisfaction and number 5 indicates the highest level satisfaction. The perceptions of 'height' and 'body weight' were asked by the questions 'I am too short - I am too tall' and 'I am too thin - I am too fat' and rated in a line segment as 1-2-5-2-1 where numbers 1 and 2 in both ends indicates unsatisfaction and 5 indicates satisfaction. The 
score of this subscale varies between 3-15 points where 9 points indicate neutral value. ${ }^{34}$

Physical activity. LTPA was determined as time spent in leisure-time physical activity outside school hours or commuting to school. LTPA was assessed with a selfadministered questionnaire and a metabolic equivalent task (MET) index (hours/week) was generated by multiplying the time spent in LTPA per week and physical activity intensity (index range $0-80 \mathrm{METh} /$ week). ${ }^{36}$ The energy cost of physical activity intensity was estimated from the existing literature. ${ }^{37}$ The MET index has previously been used in several studies. ${ }^{38-40}$

Time spent in LTPA was estimated by the question `How many hours per week are you physically active or exercise in your leisure time outside school?’' The choices were: (1) at least seven hours, (2) 4-6 hours, (3) 2-3 hours, (4) about an hour, (5) about a half an hour and (6) not at all

Intensity of LTPA was estimated by inquiring 'Which of the following alternatives describes your physical activity the best?' I engage in physical activity so that I: (1) sweat and become heavily breathless, (2) sweat and become somewhat breathless, (3) sweat but do not become breathless, (4) sweat and become slightly breathless, (5) do not sweat or become breathless, (6) don't do physical activity at all.

\section{Procedure}

Children and their parents were informed about the study and were invited to participate by a contact teacher at each school. The contact teacher also ensured that all participating children and their guardians gave a written informed consent to participate at all time points. The baseline and follow-up data were collected during school days in 
class by the contact teacher.

Children completed the questionnaires in electronic or paper form depending on the availability of computers at the schools. A pilot study was performed for both versions of the questionnaires.

\section{Data Analysis}

Mixed models with subject as a random effect were used to study the association of age and sex with the outcome variables physical activity and self-perceived physical competence. Cumulative logit models were used to study the associations between age and sex and the physical activity and self-perceived physical competence. A GEE (generalized estimating equation) method was used to account for repeated observations. The magnitudes of the associations were measured as odds ratios (OR) and their 95\% confidence intervals (CI). When the association between self-perceived physical competence and LTPA was studied, the predictor variables used in the model were age, sex, perceived competence, interaction between age and perceived competence, and interaction between sex and perceived competence. The Statistical software SAS ® System for Windows (version 9.3) was used.

\section{RESULTS}

\section{Self-perceived Physical Competence}

At age 15 years children perceived their physical fitness most often to be at a low level compared to their prior answers at 10 or 12 years old (Table 1). When aged 15 years, $14 \%$ were unsatisfied with their physical skills (one of the two lowest choices on the answer scale), as the corresponding percentage at the ages of 10 and 12 years was 
$7 \%$. A total of $10-12 \%$ of 15 -year-olds were unsatisfied with their agility, endurance, speed and strength when they compared themselves with others of their age. In mobility item, $24 \%$ of 15 -year-olds perceived their mobility to be low, as the corresponding percentage at the age of 10 years was $11 \%$ and at 12 years $15 \%$.

The analysis of perceived appearance (Table 1) indicated that 54-69\% of the 10-, 12- and 15-year-olds were satisfied with their appearance and $22-31 \%$ felt neutral (neither good nor bad) about their appearance. In more detail, at the age of 15 years $16 \%$ were unsatisfied with their appearance, as the corresponding percentage at the age of 12 years was $13 \%$ and at 10 years $9 \%$. In total, $57-64 \%$ of the $10-, 12-$ and 15 -yearolds were satisfied with their height and body weight.

[Table 1]

The perceived physical competence and perceived fitness changed across the ages (Table 2). More specifically, the total scores of self-perceived physical competence and perceived physical fitness were different from 10 and 12 to 15 years of age but not from 10 to 12 years of age. The changes in perceived appearance scores were different from 10 to 15 years but not in any other comparisons. Sex was related to self-perceived physical competence $(\mathrm{p}=.0006)$; boys perceived their physical competence better as compared to girls.

[Table 2]

\section{Leisure-time Physical Activity}

LTPA increased with age (Table 3) and boys reported higher physical activity levels than girls at ages 12 and 15. The increase in MET index with age was explained 
by the increase in physical activity intensity. The proportion of 15 -year-olds in the highest, 10 METs intensity group, was $25 \%$ compared to $16 \%$ at age 12 and $11 \%$ at age 10. In contrast, the proportion of those who spent less than 1 hour in LTPA weekly was $38 \%$ at age 15 while the figure was $17 \%$ at age 10 years and $12 \%$ at age 12 years. The changes in MET index, duration and intensity of LTPA across ages are reported in Table 4.

[Table 3]

[Table 4]

\section{Association of Self-perceived Physical Competence and LTPA}

Children's age had a significant interaction with self-perceived physical competence $(\mathrm{p}<.05)$ and perceived fitness $(\mathrm{p}=.0005)$ but not with perceived appearance $(\mathrm{p}=.554)$ (Table 5). At each age $(10,12$ and 15 years), the LTPA was significantly associated with self-perceived physical competence and with the subscale of perceived fitness. The association of LTPA and self-perceived physical competence was stronger at age 12 and 15 than at age 10 years.

We found that when the self-perceived physical competence score increased, LTPA was more likely to increase than if the self-perceived physical competence score remained unchanged. Odds ratios indicated that a one point increase in physical competence score increased the probability of intense LTPA by $11 \%$ at the age of 10 , $16 \%$ at the age of 12 and $15 \%$ at the age of 15 . One point increase in physical fitness score increased the probability of intense LTPA by $18 \%$ at the age of $10,27 \%$ at the age of 12 and $28 \%$ at the age of 15 (Table 5). Thus, children's positive perceptions of their physical competence, was related to higher LTPA. 


\section{DISCUSSION}

Children perceived their physical competence most often as being poor at the age of 15 years as compared to their answers at the ages of 10 or 12 years. The components that were perceived as being poorest at the age of 15 years were physical skills and mobility. Totally $16 \%$ of 15 -year-olds rated their physical appearance as poor, yet, when aged 10 years the children were least satisfied with their height compared to their answers at the ages of 12 or 15 . These results are likely to be partly due to normal development, growth and puberty, however the self-perceived physical competence is an important construct of self-esteem ${ }^{2}$, and thus, the results should be considered carefully.

Interestingly, LTPA determined by the MET index increased with age. The increase in the MET h/week with age was explainable with the increase of the activity intensity with age. At the age of 15 , children reported higher LTPA intensity than at the age of 10 or 12 years, whereas, a larger number of children at 15 years of age reported lower weekly duration of LTPA than at 10 or 12 years old.

The main results of this study suggest that children who had more positive perceptions of their physical competence reported higher LTPA levels than those with poorer perception of their physical competence. We also found that a change in the selfperceived physical competence scores were likely to increase LTPA at every studied age $(10,12$ and 15$)$ but more strongly at the ages of 12 and 15 than at age of 10 . The association was weakest at 10 years of age in line with our hypothesis about the 
association becoming stronger with age.

Earlier studies have presented similar results about the association of selfperceived physical competence and physical activity in children and adolescents. ${ }^{28,41}$ However, the longitudinal study is our advantage. The strength of our study is that the data are longitudinally collected from the same cohort enabling to describe and understand the phenomena that are intrinsically longitudinal, such as the development and behavior change of the child. ${ }^{42}$ The cohort consists of a segment of people that share common characteristics such as age and the place of residence. This strengthens the statistical inference about the associations as the sampling errors are minimized. ${ }^{43}$ This study gives an overview of the self-perceived physical competence and physical activity of one Finnish city's child population aged 10, 12 and 15 years. The sample is likely to represent the whole Finnish child population of corresponding age relatively well.

Future research is recommended to investigate further the direction of the association of these two concepts and to develop and evaluate interventions that attempt to influence self-perceived physical competence positively at schools and physical activity programmes. In addition, to reach a better fit between the awareness of the benefits of physical activity and the realization of them, information about the determinants and correlates of involvement and engagement in physical activity is still needed.

Our results are important when developing physical activity interventions for children and adolescents at schools or for health promotion purposes in health care settings. Hence, by striving to positively influence psychological variables ${ }^{44}$, such as the self-perceived physical competence, it is possible to increase children's physical 
activity.

\section{Limitations}

As a limitation of this study, we used questionnaire instead of objective methods to estimate LTPA levels of the subjects. However, previous studies suggest that the questionnaire characterizes the subjects acceptably according to their long-term activity levels. ${ }^{40}$ In addition, the physical activity questionnaire has been shown to correlate reasonably well with the accelerometer data. ${ }^{45}$

\section{Conclusion}

Self-perceived physical competence is associated with LTPA in children and adolescents, and the association is strengthened with age.

\section{IMPLICATIONS FOR SCHOOL HEALTH}

Based on our results, self-perceived physical competence is positively associated with physical activity and the association is strengthened with age. An increase in selfperceived physical competence is likely to associate with higher physical activity at ages 10,12 , and 15 . Thus, by promoting self-perceived physical competence it may be possible to promote children's physical activity. Self-perceived physical competence is enhanced through positive feedback and feelings of success.

By offering a wide range of physical activity experiences throughout childhood, schools have an important role in enhancing children's self-perceived physical competence, physical activity, and, further, in health promotion. 
The actions towards promoting children's self-perceived physical competence and physical activity do not need much time or economical resources. The most important challenge to overcome is to change the cultural climate and attitudes. It is important that actions are made at various levels and involve schools, political decision-makers, parents, and health care personnel working with children.

\section{Actions Related to Schools}

- Teachers have an opportunity to provide a framework and organize situations for success for all. This may be accomplished by offering the possibility of a wide range of physical activity experiences and the possibility for individual choices to the extent possible within the curriculum. It is important to listen to children's viewpoints and include them in decision-making in an age-appropriate way.

- Teachers can facilitate a positive and supportive social climate and students' interaction during physical education classes, instead of enhancing competitive settings at all times. Facilitating interaction and group spirit could be continued beyond the physical education class setting.

- Assessment in physical education serves many purposes and impacts on children's self-perceived physical competence. To supplement quantitative methods, assessment of student performance with qualitative methods is warranted.

\section{Actions Related to Political Decision-makers}

- To be able to provide a wide range of physical activity experiences and feelings of success at schools, political decisions-makers should value and weight actions towards an environment promoting physical activity at schools, in school yards, and 
in the school neighbourhood.

\section{Actions Related to Parents}

- Parents have the responsibility to provide opportunities for versatile physical activities for their children outside school days. To promote self-perceived physical competence, physical activities should be enjoyable, fun, and bring positive experiences.

\section{Actions Related to Health Care Personnel Working with Children}

- Health care personnel have an important role in bringing physical activity benefits and habits into discussion with children in school health checkups. Health care personnel may also seek solutions with teachers to encourage children to partake in physical activity, activate the school days, and reduce sedentary time in classes and on breaks.

\section{HUMAN SUBJECTS APPROVAL STATEMENT}

This study was approved by the Ethical commission of the Hospital District of Southwest Finland (8/2004/232). All study subjects and their guardians gave written informed consent to participate in this study.

\section{ACKNOWLEDGEMENTS}

This study has been financially supported by grants from the Juho Vainio Foundation, City of Turku, the Turku University Foundation and the Doctoral Programme in Nursing Science University of Turku, Finland. 


\section{REFERENCES}

1. Sonstroem RJ. Physical self-concept: assessment and external validity. Exerc Sport Sci Rev. 1998;26:133-164.

2. Lintunen T. Perceived physical competence scale for children. Scand J Med Sci Sports. 1987;9(1):57-64.

3. Bandura A. Self-efficacy: the Exercise of Control. New York: W.H. Freeman; 1997.

4. Lewis BA, Marcus BH, Pate RR, Dunn AL. Psychosocial mediators of physical activity behavior among adults and children. Am J Prev Med. 2002;23:26-35.

5. Sonstroem RJ, Morgan WP. Exercise and self-esteem: rationale and model. Med Sci Sports Exerc. 1989;21:329-337.

6. Whitehead JR, Corbin CB. Self-esteem in children and youth: the role of sport and physical education. In The Physical Self: From Motivation to Well-being, edited by Fox KR, 175-203. Champaign IL, US: Human Kinetics. 1997.

7. WHO. Global recommendations on physical activity for health; 2010. Available at: http://www.who.int/dietphysicalactivity/publications/9789241599979/en/index.html Accessed June 8, 2016.

8. Strong WB, Malina RM, Blimkie CJ, Daniels SR, Dishman RK, Gutin B, et al. Evidence based physical activity for school-age youth. J Pediatr. 2005;146:732737.

9. Tammelin, T., Karvinen, J. (eds.). Fyysisen Aktiivisuuden Suositus Kouluikäisille 718-vuotiaille. [Recommendations on Physical Activity for 7-18 Years Old.] Helsinki: Opetusministeriö \& Nuori Suomi ry; 2008. 
10. Lee IM, Shiroma EJ, Lobelo F, Puska P, Blair SN, Katzmarzyk PT, et al. Effect of physical inactivity on major non-communicable diseases worldwide: an analysis of burden of disease and life expectancy. Lancet. 2012;380:219-229.

11. Gallahue DL, Ozmun JC, Goodway JD: Understanding Motor Development: Infants, Children, Adolescents, Adults. New York: McGraw-Hill; 2012.

12. Hallal PC, Victora CG, Azevedo MR, Wells JC. Adolescent physical activity and health: a systematic review. Sports Med. 2006;36:1019-1030.

13. Telama R, Yang X, Leskinen E, Kankaanpää A, Hirvensalo M, Tammelin T, et al. Tracking of physical activity from early childhood through youth into adulthood. Med Sci Sports Exerc. 2014;46:955-962.

14. Williams HG, Pfeiffer KA, O'Neill JR, Dowda M, McIver KL, Brown WH, et al. Motor skill performance and physical activity in preschool children. Obesity (Silver Spring). 2008;16:1421-1426.

15. Cliff DP, Okely AD, Smith LM, McKeen K. Relationships between fundamental movement skills and objectively measured physical activity in preschool children. Pediatr Exerc Sci. 2009;21:436-449.

16. Piek JP, Dawson L, Smith LM, Gasson N. The role of early fine and gross motor development on later motor and cognitive ability. Hum Mov Sci. 2008;27:668-681.

17. Kantomaa MT, Stamatakis E, Kankaanpaa A, Kaakinen M, Rodriguez A, Taanila A, et al. Physical activity and obesity mediate the association between childhood motor function and adolescents' academic achievement. Proc Natl Acad Sci U S A. 2013;110:1917-1922.

18. Tremblay MS. Global summit on the physical activity of children. J Phys Act Health. 2014;11:1-2. 
19. Riddoch CJ, Bo Andersen L, Wedderkopp N, Harro M, Klasson-Heggebo L, Sardinha LB, et al. Physical activity levels and patterns of 9- and 15-yr-old European children. Med Sci Sports Exerc. 2004;36:86-92.

20. Currie $\mathrm{C}$ et al., eds. Social determinants of health and well-being among young people. Health behaviour in school-aged children (HBSC) study: international report from the 2009/2010 survey. Copenhagen, WHO Regional Office for Europe, 2012. Health Policy for Children and Adolescents 2012;6.

21. Aira T, Kannas L, Tynjälä J, Kokko S. Hiipuva liikunta nuoruusiässä. Drop off ilmiön aikatrendejä ja kansainvälistä vertailua WHO-Koululaistutkimuksen (HBSCStudy) aineistolla 1986-2010. [Exercise fading in adolescence. Drop-off phenomenon's time trends and international comparison of the WHO's Health behaviour in school-aged children -survey (HBSC-Study), data from 1986 to 2010]. Terveyden edistämisen tutkimuskeskuksen julkaisuja 5. Jyväskylän yliopisto; 2013.

22. OECD. Health at a Glance 2013: OECD Indicators, 2013. Available at: http://www.oecd.org/els/health-systems/Health-at-a-Glance-2013.pdf. Accessed June 8, 2016.

23. STM. Muutosta Liikkeellä! Valtakunnalliset Yhteiset Linjaukset Terveyttä ja Hyvinvointia Edistävään Liikuntaan 2020. [Change on the move! Nationwide guidelines for the health and welfare enhancing physical activity in 2020]. Sosiaalija terveysministeriön julkaisuja 2013;10.

24. Koski P, Tähtinen J. Liikunnan merkitykset nuoruudessa. [Meanings of exercise in adolescence]. Nuorisotutkimus - Liikunta 2005;1.

25. Biddle SJH, Murtie N. Psychology of Physical Activity: Determinants, Well-being, and Interventions. Abingdon, Oxon: Routledge; 2008. 
26. Aaltonen S, Kujala UM, Kaprio J. Factors behind leisure-time physical activity behavior based on Finnish twin studies: the role of genetic and environmental influences and the role of motives. Biomed Res Int. 2014;931820.

27. Aeffect Inc. Review of Literature to Support Development of the Youth Media campaign - Exploring How to Motivate Behavior Change among Tweens in America. Available at: http://www.cdc.gov/youthcampaign/research/pdf/litreview.pdf Accessed June 8, 2016.

28. Sallis JF, Prochaska JJ, Taylor WC. A review of correlates of physical activity of children and adolescents. Med Sci Sports Exerc. 2000;32:963-975.

29. Sports Council and Health Education Authority. Allied Dunbar National Fitness Survey for England: Main findings. 1992; Northampton: Sports Council, Health Education Authority.

30. von Elm E, Altman DG, Egger M, Pocock SJ, Gøtzsche PC, Vandenbroucke JP. The Strengthening the reporting of observational studies in epidemiology (STROBE) statement: guidelines for reporting observational studies. PLoS Med. 2007;4(10):e296.

31. Laaksonen C, Aromaa M, Heinonen OJ, Koivusilta L, Koski P, Suominen S, et al. Health related quality of life in 10-year-old schoolchildren. Quality of Life Research: Qual Life Res. 2008;17:8:1049-1054.

32. Laaksonen CB, Aromaa M, Asanti R, Heinonen OJ, Koivusilta L, Koski P, et al. The change in child self-assessed and parent proxy-assessed health related quality of life (HRQL) in early adolescence (age 10-12). Scand J Public Health. 2010;38:1:9-16. 
33. Lintunen T. Self-perceptions, fitness, and exercise in early adolescence: A four-year follow-up study. Studies in sport, physical education and health 41, Jyväskylä: University of Jyväskylä; 1995.

34. Lintunen T. Development of self-perceptions during the school years. In Auweele YV, Bakker F, Biddle S, Durand M, Seiler R. (eds.) Psychology of Physical Educators. Champaign, IL: Human Kinetics; 1999:115-134.

35. Lintunen T, Heikinaro-Johansson P, Sherrill C. Use of the perceived physical competence scale with adolescents with disabilities. Percept Mot Skills. 1995;80:571577.

36. Raitakari OT, Taimela S, Porkka KV, Leino M, Telama R, Dahl M, et al. Patterns of intense physical activity among 15- to 30-year-old Finns. The cardiovascular risk in young Finns study. Scand J Med Sci Sports. 1996;6:36-39.

37. Ainsworth BE, Haskell WL, Herrmann SD, Meckes N, Bassett DR,Jr, Tudor-Locke C, et al. 2011 Compendium of physical activities: a second update of codes and MET values. Med Sci Sports Exerc. 2011;43:1575-1581.

38. Mansikkaniemi K, Juonala M, Taimela S, Hirvensalo M, Telama R, Huupponen R, et al. Cross-sectional associations between physical activity and selected coronary heart disease risk factors in young adults. The cardiovascular risk in young Finns study. Ann Med. 2012;44:733-744.

39. Pahkala K, Hernelahti M, Heinonen OJ, Raittinen P, Hakanen M, Lagstrom H, et al. Body mass index, fitness and physical activity from childhood through adolescence. Br J Sports Med. 2013;47:71-77.

40. Palve KS, Pahkala K, Magnussen CG, Koivistoinen T, Juonala M, Kahonen M, et al. Association of physical activity in childhood and early adulthood with carotid 
artery elasticity 21 years later: the cardiovascular risk in young Finns study. $J$ Am Heart Assoc. 2014;3:e00594.

41. Van Der Horst K, Paw MJ, Twisk JW, Van Mechelen W. A brief review on correlates of physical activity and sedentariness in youth. Med Sci Sports Exerc. 2007;39:1241-1250.

42. White RT, Arzi HJ. Longitudinal studies: designs, validity, practicality, and value. Res Sci Educ. 2005;35:137-149.

43. Friis RH, Sellers TA. Epidemiology for Public Health Practice. Burlington, MA: Jones \& Bartlett Learning; 2014.

44. Baranowski T, Jago R. Understanding the mechanisms of change in children's physical activity programs. Exerc Sport Sci Rev. 2005;33:163-168.

45. Lehtonen-Veromaa M, Möttönen T, Svedström E, Hakola P, Heinonen OJ, Viikari J. Physical activity and bone mineral acquisition in peripubertal girls. Scand J Med Sci Sports. 2000;10:236-243. 


\section{TABLES}

Table 1. The Levels of Self-perceived Physical Fitness and Appearance of the Children Studied at Ages of 10, 12 and 15 Years

\begin{tabular}{|c|c|c|c|c|}
\hline Component & $\begin{array}{c}\text { Level of } \\
\text { self-perception }\end{array}$ & $\begin{array}{c}10 \text { years }(\mathrm{N}=\mathbf{5 3 0}) \\
\%\end{array}$ & $\begin{array}{c}12 \text { years }(\mathrm{N}=479) \\
\%\end{array}$ & $\begin{array}{c}15 \text { years }(\mathrm{N}=\mathbf{5 0 1}) \\
\%\end{array}$ \\
\hline \multirow[t]{2}{*}{ Physical skills } & low* & 7 & 7 & 14 \\
\hline & high** & 66 & 68 & 60 \\
\hline \multirow[t]{2}{*}{ Agility } & low* & 6 & 6 & 10 \\
\hline & high** & 76 & 71 & 65 \\
\hline \multirow[t]{2}{*}{ Mobility } & low* & 11 & 15 & 24 \\
\hline & high** & 50 & 45 & 40 \\
\hline \multirow[t]{2}{*}{ Endurance } & low* & 8 & 6 & 10 \\
\hline & $\operatorname{high}^{* *}$ & 70 & 70 & 60 \\
\hline \multirow[t]{2}{*}{ Speed } & low* & 8 & 9 & 13 \\
\hline & high** & 67 & 64 & 59 \\
\hline \multirow[t]{2}{*}{ Strength } & low* & 8 & 5 & 12 \\
\hline & high** & 66 & 64 & 61 \\
\hline \multirow[t]{2}{*}{ Courage } & low* & 9 & 7 & 9 \\
\hline & high** & 67 & 70 & 64 \\
\hline \multirow[t]{2}{*}{ Appearance } & low ${ }^{1}$ & 8 & 13 & $\overline{16}$ \\
\hline & high $^{2}$ & 68 & 57 & 54 \\
\hline \multirow[t]{2}{*}{ Height } & low $w^{3}$ & 13 & 10 & 9 \\
\hline & satisfied $^{4}$ & 61 & 59 & 57 \\
\hline \multirow[t]{2}{*}{ Body weight } & $\operatorname{low}^{3}$ & 7 & 5 & 7 \\
\hline & satisfied $^{4}$ & 62 & 66 & 62 \\
\hline
\end{tabular}

* one of the two lowest choices on the response scale

** one of the two highest choices on the response scale

${ }^{1}$ one of the two lowest choices on the response scale

${ }^{2}$ one of the two highest choices on the response scale

${ }^{3}$ the lowest level of satisfaction (1 point)

${ }^{4}$ satisfied (5 points) 
Table 2. Changes in Perceived Fitness, Perceived Appearance and Self-perceived Physical Competence of the Children Studied Across the Ages of 10, 12 and 15 years

\begin{tabular}{|c|c|c|c|c|c|c|c|c|c|}
\hline Component & Age & $\begin{array}{c}\mathbf{1 0} \\
\mathrm{N}=52 \\
7\end{array}$ & $\begin{array}{c}12 \\
\mathrm{~N}=47 \\
9\end{array}$ & $\begin{array}{c}15 \\
N=49 \\
8\end{array}$ & & $\begin{array}{c}10 \text { vs. } \\
12 \\
\text { years } \\
\text { old }\end{array}$ & $\begin{array}{c}12 \text { vs. } \\
15 \\
\text { years } \\
\text { old }\end{array}$ & $\begin{array}{c}10 \text { vs. } \\
15 \\
\text { years } \\
\text { old }\end{array}$ & $\begin{array}{c}\text { All } \\
\text { girls } \\
\text { vs. all } \\
\text { boys }\end{array}$ \\
\hline & & & & & $\mathbf{p}^{*}$ & $\mathbf{p}$ & $\mathbf{p}$ & $\mathbf{p}$ & $\mathbf{p}$ \\
\hline $\begin{array}{l}\text { Perceived } \\
\text { fitness }\end{array}$ & $\mathrm{M}$ & 26.5 & 26.4 & 25.4 & $<.0001$ & 0.31 & $<.0001$ & $<.0001$ & .02 \\
\hline $\begin{array}{l}\text { Perceived } \\
\text { appearance }\end{array}$ & M & 11.4 & 11.2 & 10.9 & .03 & .3 & .12 & .01 & $<.0001$ \\
\hline $\begin{array}{l}\text { Perceived } \\
\text { physical } \\
\text { competence }\end{array}$ & M & 37.9 & 37.5 & 36.3 & $<.0001$ & .17 & $<.0001$ & .0001 & .0006 \\
\hline
\end{tabular}


Table 3. Mean Leisure-time Physical Activity Metabolic Equivalent of Task (MET) -Index of the Children Studied at the Ages of 10, 12 and 15 Years

\begin{tabular}{lcccc}
\hline & & 10 years & 12 years & 15 years \\
\hline Mean & All & 24.6 SD 19.4 & 29.8 SD 21.4 & 33.9 SD 26.3 \\
METh/week & & $(\mathrm{N}=529 / 571)$ & $(\mathrm{N}=515 / 571)$ & $(\mathrm{N}=508 / 571)$ \\
& \multirow{2}{*}{ Girls } & 23.2 SD 18.4 & 25.9 SD 18.7 & 31.4 SD 25.2 \\
& & $(\mathrm{N}=280 / 299)$ & $(\mathrm{N}=278 / 299)$ & $(\mathrm{N}=271 / 299)$ \\
& \multirow{2}{*}{ Boys } & 26.2 SD 20.4 & 34.4 SD 23.5 & 36.9 SD 27.3 \\
& & $(\mathrm{N}=249 / 272)$ & $(\mathrm{N}=237 / 272)$ & $(\mathrm{N}=237 / 272)$ \\
\hline & & $\mathrm{p}=.1368$ & $\mathrm{p}<.0001$ & $\mathrm{p}=.0082$ \\
\hline
\end{tabular}


Table 4. Changes in Metabolic Equivalent of Task (MET) -Index and Reported Duration and Intensity of Leisure-time Physical Activity (LTPA) of the Children Studied Across the Ages of 10, 12 and 15 Years

\begin{tabular}{lcccc}
\hline Component & $\begin{array}{c}\mathbf{1 0} \text { vs. 12 years } \\
\text { old }\end{array}$ & $\begin{array}{c}12 \text { vs. 15 years } \\
\text { old }\end{array}$ & $\begin{array}{c}\text { 10 vs. 15 years } \\
\text { old }\end{array}$ \\
\hline & $\mathbf{p}^{*}$ & $\mathbf{p}$ & $\mathbf{p}$ & $\mathbf{p}$ \\
LTPA duration & $<.0001$ & $<.0001$ & .68 & $<.0001$ \\
LTPA intensity & $<.0001$ & $<.001$ & $<.0001$ & $<.001$ \\
MET-index & $<.0001$ & $<.0001$ & .06 & $<.0001$ \\
\hline
\end{tabular}

*analysis of all three groups (10,12 and 15 years old) 
Table 5. The Association of the Metabolic Equivalent of Task (MET) -Index with Self-perceived Physical Competence and Its Subscales Perceived Fitness and Perceived Appearance in the Children Studied

\begin{tabular}{|c|c|c|c|c|c|c|}
\hline Predictor & & $\begin{array}{c}\text { Interaction } \\
\text { p value }\end{array}$ & $\begin{array}{l}\text { P value for } \\
\text { physical } \\
\text { competence }\end{array}$ & $\mathbf{O R}$ & $\begin{array}{c}\text { Lower } \\
95 \% \mathrm{CI}\end{array}$ & $\begin{array}{c}\text { Upper } \\
95 \% \text { CI }\end{array}$ \\
\hline \multirow[t]{4}{*}{ Perceived fitness } & & .0005 & & & & \\
\hline & 10 years & & $<.0001$ & 1.18 & 1.09 & 1.27 \\
\hline & 12 years & & $<.0001$ & 1.27 & 1.18 & 1.37 \\
\hline & 15 years & & $<.0001$ & 1.28 & 1.19 & 1.38 \\
\hline Perceived appearance & & .554 & .01 & 1.04 & 1.01 & 1.08 \\
\hline \multicolumn{7}{|l|}{ Perceived physical } \\
\hline \multirow[t]{4}{*}{ competence (total) } & & $<.05$ & & & & \\
\hline & 10 years & & .001 & 1.11 & 1.04 & 1.17 \\
\hline & 12 years & & $<.0001$ & 1.16 & 1.09 & 1.23 \\
\hline & 15 years & & $<.0001$ & 1.15 & 1.09 & 1.22 \\
\hline
\end{tabular}

